\title{
THE COMPETITIVENESS CHALLENGE IN EAST JAVA UNDER THE ASEAN ECONOMIC COMMUNITY DISRUPTIVE ERA
}

\author{
Farida Rahmawati ${ }^{1}$, Hadi Sumarsono ${ }^{2}$, Ahmad Fawaiq Suwanan $^{3}$, Ermita Yusida ${ }^{4 *}$, Inayati Nuraini Dwiputri ${ }^{5}$ \\ $1,2,3,4,5$ Universitas Negeri Malang, Malang, Indonesia. \\ Email: ${ }^{1}$ farida.rahmawati.fe@um.ac.id, ${ }^{2}$ hadi.sumarsono.fe@um.ac.id, ${ }^{3}$ afawaiq@gmail.com, \\ 4* ermita.yusida.fe@um.ac.id, 5inayati.dwiputri.fe@um.ac.id
}

Article History: Received on $31^{\text {st }}$ October 2019, Revised on $29^{\text {th }}$ November 2019, Published on $31^{\text {st }}$ December 2019

\begin{abstract}
Purpose of the study: According to the data, there have been some competition challenges in Indonesia's sub-national level under the ASEAN Economic Community (AEC) scheme. Thisresearchaimsto examines the challenge of competitiveness in East Java, Indonesia, after the implementation of AEC.
\end{abstract}

Methodology: This research implements the comparative advantage using Revealed Comparative Advantage (RCA) Analysis which is measured by calculating the share of export value of East Java products to total exports to the importing country. It can be known as the quantitative ability or inability to compete in the importer country in the world.

Main Findings: The diversification of new commodities has become a potential outcome. Provinces that have higher advanced in international trade will gain more from trade than those which have limited access from trade. Agriculture products and their supply chain in East Java benefit more as they are the region's specialization compare to other commodities.

Applications of this study: The results of this study can be taken into consideration for better policy recommendations and can be a benchmark for other provinces in Indonesia as well as another region that mainly depends on the agriculture sector. Specializing the comparative advantages will be substantial to gain from trade because the majority of export growth is competitive under the Asean Economic Community disruptive era.

Novelty/Originality of this study: Conducting research on comparative advantage dynamics is essential and relatively new for East Java as international trade is important variables in influencing the regional economic growth.

Keywords: Competitiveness, Balassa Revealed Comparative Advantage, Agriculture Commodities, East Java.

JEL Classification: F11, F14.

\section{INTRODUCTION}

To integrate the Association of Southeast Asia Nations (ASEAN) economy, a free trade system between ASEAN countries was established, known as the ASEAN Economic Community (AEC) or the ASEAN Economic Community (AEC). The ASEAN Economic Community (AEC) is a single market in the ASEAN region whose one goal is to increase investment in the ASEAN region. With the AEC, Indonesia as an ASEAN region triggers trade flows for goods and services more easily. This can make the ASEAN region a more competitive economic region and integrated into the global market. With the AEC, it is easier for foreign products to enter Indonesia. Therefore the competition between business actors in ASEAN becomes increasingly stringent which triggers efforts to improve product quality at more competitive prices.

The advent of the ASEAN economic community (AEC) integration proposes a new era in regional efforts to forge stronger cooperation and closer relations among the ASEAN member states. By implementing the AEC, members of ASEAN may gain greater competitiveness and equitable economic development through better investment and competitiveness. In the sub-national area, AEC could gain more from trade as the region is more connected. Also, AEC will trigger the level of the economic scale to support the member countries' development goals (Green, 2008; Majid, 2006).

East Java, the second-largest provinces in Indonesia with more than 37 million people, with a share of almost $15 \%$ share on agro-exports experiences in Java Island (BPS, 2019). East Java is also home for a large number of Micro, Small and Medium Enterprises (MSMEs). The implementation of AEC can boost the leverage of UMKM in East Java, then will affect the rate of competitiveness of East Java Province. Therefore East Java will be interesting in understanding the impact of the AEC on investment and competitiveness.

According to Hseng (2015) and Khee Giap Tan, Mulya Amri, Nurina Merdikawati (2018) AEC can create ease of doing business than increasing the Foreign Direct Investment (FDI) and economic growth. In terms of competitiveness, AEC can have both positive and negative impacts because, with the AEC, imported products will flood markets without any barrier. Discussing the cost-benefit analysis of AEC, on one hand, consumers will be able to benefit because high competition can increase consumer surplus. However, on the other hand, a large number of imported products on the market may create predatory competition between local products and imported products. Nevertheless, openness in trade 
can have a positive impact on economic growth (Emiko, 2010). With good competitiveness, it will trigger an increase in exports then propose a higher trade balance surplus.

This study assesses the impact of competitiveness in East Java Province under the AEC disruptive era. This is a substantial agenda because competitiveness is important variables in influencing the economic growth and economy as East Java is part of an integrated global economy. The results of this study can be taken into consideration for better policy recommendations and can be a benchmark for other provinces in Indonesia.

\section{LITERATURE REVIEW}

The economic community is not only beneficial in economic terms but also in a political sense related to competitiveness within countries (Tongzon, 2003). Competitiveness has a range of terminologies. Often the supporters of competitiveness emphasize the level of sustainable productivity growth, especially in terms of producing products that meet the global market needs and are able to lead to a better standard of living.

The World Economic Forum study (2018) publishes The Global Competitiveness Index (GCI) which shows a strong correlation between competitiveness and income level. Countries with high incomes constitute the top 20 competitive countries. In contrast, only three countries that are not able to gain high-income countries. For instance, Malaysia (25), China (28th), and Thailand (38th) were ranked in the top 40. There are middle-income countries - including Malaysia, Mexico, Indonesia, and India - that show improved competitiveness performance. If this is maintained, in the future, there will be a higher and sustainable increase in income.

The 2018 GCI also mentions Indonesia ranked 45th out of 140 countries, with an overall score (64.9). Indonesia's position increases two places compared to 2017 which ranked 47th. Although known as the largest economic player in Southeast Asia in terms of size and population, Indonesia ranks only 4th in ASEAN behind Singapore (2), Malaysia (25), and Thailand (38).

GCI 2018 itself is developed based on the twelve competitiveness dimensions. The index is consists of 98 total indicators, developed from the accumulation of data not only from global organizations but also from a survey of the executive opinions from the World Economic Forum. The report is organized into 12 pillars in GCI 4.0 that reflect the level of complexity, productivity, and ecosystem competitiveness. The twelve pillars include institution, infrastructure, adoption of information technology, macroeconomic stability, health, skills, production markets, labor markets, financial systems, market size, business dynamics, and innovation capabilities.

Competitiveness has been defined as the ability to compete in the past, in the present, and in the future. Competitiveness is a dynamics during the period of time and to some extent depends on the level of competitiveness, demand behavior, and the industrial capacity in the country (WEF, 2018). Some economists explain that global competitiveness is closely related to the comparative advantage as well as the price factor. Those views are mostly inspired by Ricardo and Hecksher-Ohlin model. Ricardo in some of his paper focused on production factor and the range of technological level, while Hecksher and Ohlin focus on the input of labor and capital, as well as comparative advantages based on endowment factors and relative price factor (Dornbusch, Rudiger, Stanley Fischer, and Richard Startz ., 1998).

\section{Comparative Advantage}

In discussing the Ricardian concept, comparative advantage usually occurs because of the dissimilarities of technology across countries, whereas the Heckscher-Ohlin theory considers cost dissimilarities that occurs due to the gap in factor prices between each nation, with constant technology. Thus, the teori of international trade in the classical economic thought is developed from the differentiation of pre-trade relative price across countries. Even though calculating the comparative advantage through Heckser-Ohlinmodel has several challenges, the relative price of pre-trade can be immeasurable (Balassa, 1989). Because of these obstacles, Balassa (1965) proposed that there is no crucial to analyze all commodities disturbing comparative advantage of any specific region rather one should analyze the trade pattern. Consequently, export data can determine the revealed comparative advantage (RCA), which is practically and commonly complied with the measure. Balassa Revealed Comparative Advantage (BRCA) Index is only paying attention in estimating the comparative advantage of specific countries instead of deeply analyze the determination of sources.

The law of comparative advantage also mentions that the less efficient countries should specialize in the trade of commodities in which its absolute disadvantage is smaller. In the other term, a nation will increase the production capacity sector with a high comparative advantage and reduce the production capacity sector with low comparative advantage. In addition, a commodity with a great export share will show a high comparative advantage measured in RCA too, at least $>1$. The comparative advantage is illustrated by the lower cost of producing a commodity in an independent or autarky situation. Therefore, ideally, theoretically, trade accumulation indices would be a more adequate and powerful measure in estimating-comparative advantage.

Gupta (2015) describes that comparative advantage principles as introduced by David Ricardo were emphasized in terms of superiority of technology, and usually associated with opportunity cost and/or market relative prices of some commodities between one country to the other countries. In addition, although Ricardian's concept in terms of comparative advantage was in static problems, the real comparative advantage is actually a dynamic problem. The 
existing comparative advantage in particular commodities can be dynamic every time subject to external factors influencing comparative advantages such as resource endowments, government policies, technological progress, specialization, business practices, demand patterns, and other potential factors. While Competitive advantage can be illustrated as the advantages that a country can be gained against competitors. For instance: a country that has low-cost structure, low cost of labor, better access to raw materials can be associated with a competitive advantage. Consequently, it can be quoted that a comparative advantage is a form of competitive advantage because the country which has a higher comparative advantage leads the country a greater competitive advantage.

Much research on comparative advantage emphasized their scope on the transformations in trade dynamics by a shift in comparative advantage. Research on comparative advantage initiate that pattern dynamics and performance are subject to not only demand and supply sides, but also domestic and global markets (Widodo, 2009). Yuea and Hua (2002) conclude that a shift in comparative advantage to the labor-based firm in China together with supply-side adjustment lead to higher economic progress as well as export benefit. Then Lee (1995), transferring resources from small to greater marginal labor productivity areas, specialization, governance, and institutions have a significant role and affect the advantage dynamics in Korea. According to those previous studies, comparative advantage dynamic is an essential study to understand the advantage and the disadvantage of some commodities in a country as well as sub-national entities. Through better knowledge in comparative advantage dynamics, the government can arrange the appropriate strategy to compete in the global market dynamics.

\section{RESEARCH METHODS}

Comparative advantage analysis is a useful method in economics that can be used to identify a market with the highest possibility of success. There are two major models that are normally chosen in calculating comparative advantage. First is the Domestic Resource Cost (DRC) and the second is Revealed Comparative Advantage (RCA) methods. The advantage of the DRC methods is more dynamic yet needs data on production cost that is usually difficult to obtain. The RCA approach has less predictive potential than the DRC and is more descriptive. The advantage of the RCA is that the required data are normally available.

This research implements a comparative advantage using the Revealed Comparative Advantage (RCA) Analysis. The performance of exports in East Java to other countries is a variable measured by calculating the share of export value of East Java products to total exports to the importing country which is then compared with the share of the export value of Indonesia to the importing country. So it can be known quantitatively the ability or inability of East Java exports to compete in the importer country. RCA calculations can be formulated in the formula below.

$$
R C A=\frac{\left(\frac{X_{i j}}{X_{j}}\right)}{\left(\frac{X_{i w}}{X_{w}}\right)}
$$

Where:

$X_{\mathrm{ij}}$ : the Export value of East Java agricultural products to the importing country of East Java

$\mathrm{X}_{\mathrm{j}}$ : The total export value of all East Java products to the importer country of East Java Agriculture

$\mathrm{X}_{\mathrm{iw}}$ : The value of world agricultural product exports to agricultural importers in East Java

$X_{w}$ : The total value of world exports to the agricultural importer country in East Java

If the RCA value is $<1$, it states that the products have no comparative advantage If the RCA value is between $1<\mathrm{x}<2$, it states that the products have low/ weak competitiveness. If the RCA value is between $2<x<3$, it states that the products have medium competitiveness. If the RCA value is above 3 , it states that the products have strong competitiveness

Agriculture was chosen because East Java's superior product is the agricultural sector.

\section{Data}

This study is limited to the Agriculture Products of East Java from 2014 to 2017. Data on Exports of East Java were collected from the Indonesian Statistic Bureau (Badan Pusat Statistik Indonesia, BPS) at 2-digit level Harmonized System - HS, based on Standard International Trade Classification-SITC (www.bps.go.id). Due to the different classification of the export products published by BPS, the author accommodated the data from BPS only after 2013. Data for the World - exports and imports- were collected from the International Trade Center (ITC) database (www.trademap.org).

\section{RESULT AND DISCUSSION}

\section{General view of ASEAN}

Global trade in goods and services, and foreign direct investment (FDI) are essential elements for the ASEAN economy. According to ASEAN Secretariat (2018), ASEAN total merchandise trade has markedly climbed nearly 3.5 times, from 
US\$ 790 billion in 2000 to US\$2,574 billion in 2017. Exports of goods persistently grew up along the estimated time, except for a financial crisis in 2009, reaching 1,322 billion dollars in 2017. During a similar period, total goods import approached US\$1,252 billion and remains below the export values, following the surplus trend of the trade balance.

Since 2000, the ASEAN trade balance has fluctuated following the gap between total export and total import of goods. The highest value of trade balance occurs in 2006, reaching almost US\$ 110 billion. While in another period, especially in 2013, the trade balance value reached only US\$ 30 billion.

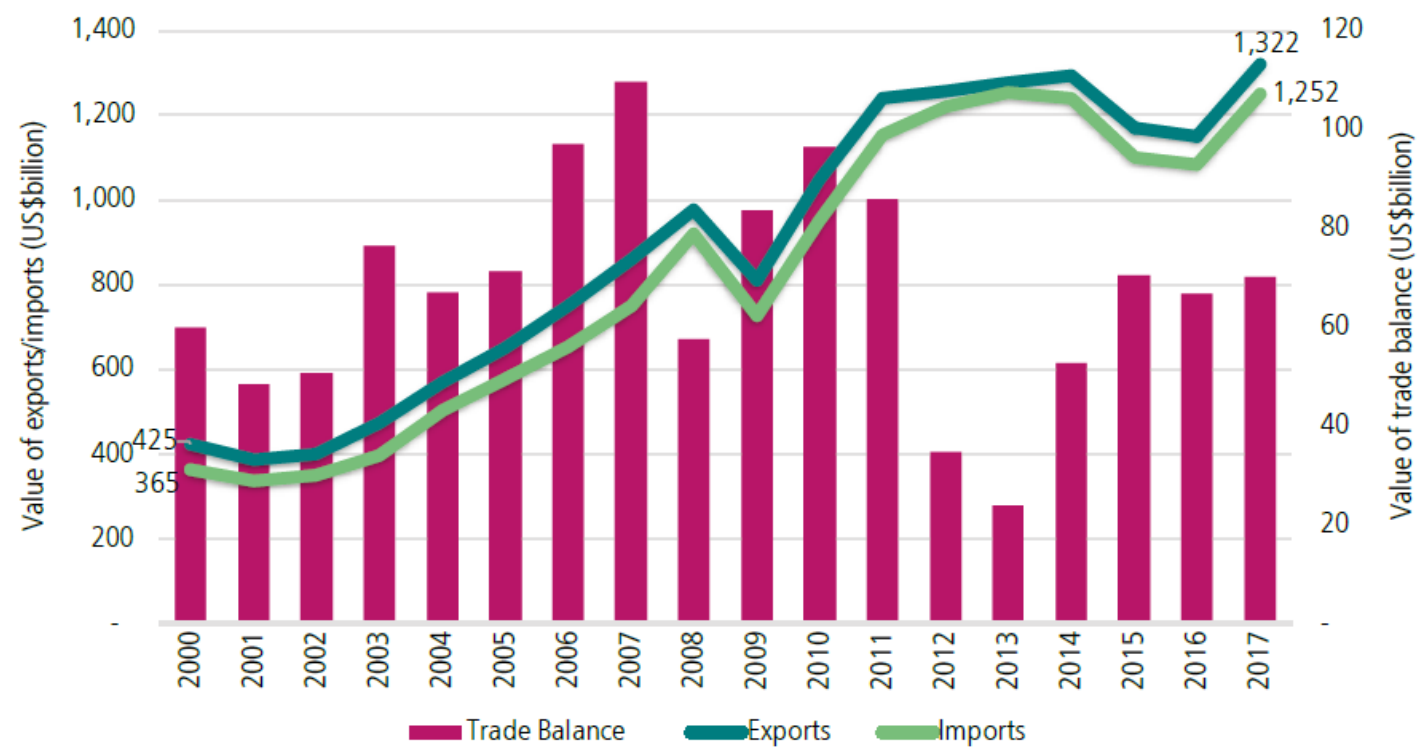

Figure 1: Exports and imports of goods and trade balance value (US\$billion), ASEAN, 2000-2017

Source: ASEAN Secretariat, ASEANstats database (2019)

Agricultural products share significant proportions to not only total exports but also imports of goods in some ASEAN member states (AMS). Figure 2 illustrates the greatest number of agricultural products to their total exports in the merchandises of AMS. It can be seen that Myanmar which has 32.2 percent in 2017 has the highest share among other AMS, continued by Lao PDR 28.9 percent and Indonesia, 21.8 percent. Following those three AMS, the Philippines has slightly climbed between 2010 to 2017. Unfortunately, the rest of the AMS exhibit a lower number of agricultural product contributions to total export in merchandises which reach for about $10 \%$ or lower, including Malaysia 10 percent, Philippines 8.8 percent, Cambodia 5.2 percent, Singapore 2.8 percent and Brunei Daressalam0.2 percent.

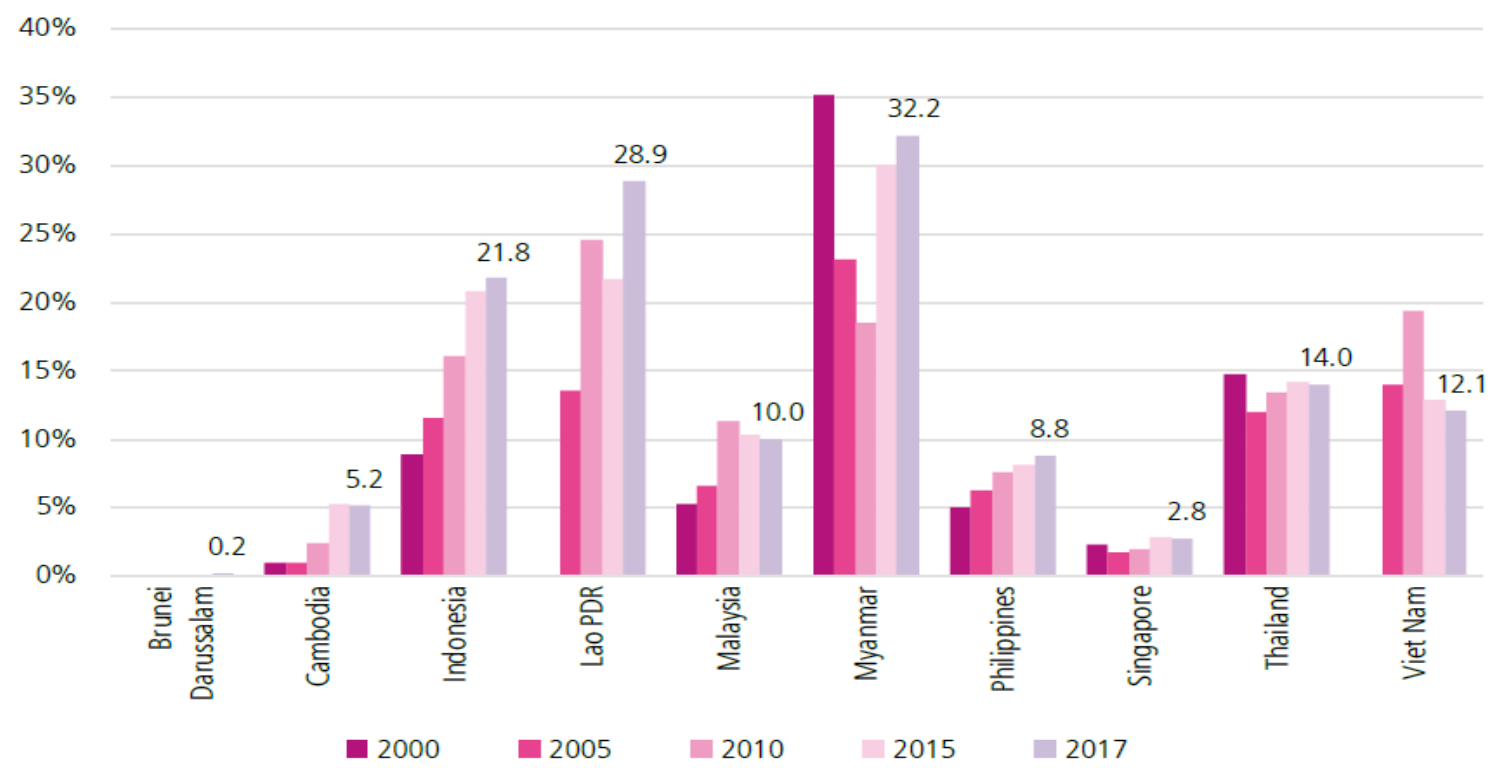

Figure 2: Share of agricultural products to total exports (\%), ASEAN Member States, 2000-2017

Source: ASEAN Secretariat, ASEANstats database (2019)

Figure 3 shows that the agro-based commodities contribution to the number of imports in merchandise was high in 2017 , including Brunei Darussalam at 15.1 percent, continued by Myanmar at 14.8 percent, Lao PDR at 13.3 percent, the 
Philippines at 12.1 percent and the Republic of Indonesia at 11.2 percent. The contribution of other remaining ASEAN countries was lower than $10 \%$, with Singapore's share at only 3.7\% in 2017.

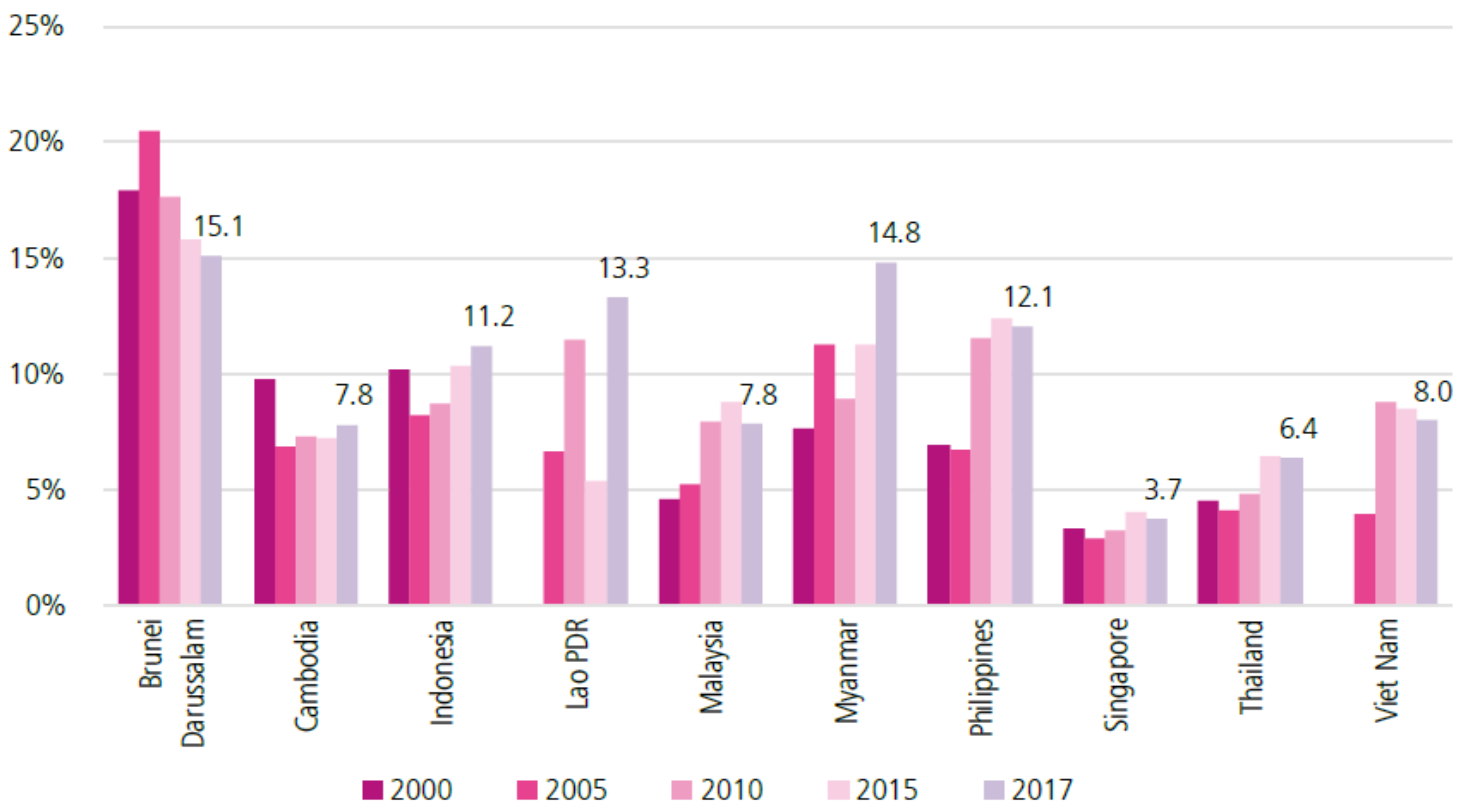

Figure 3: Share of agricultural products to total imports (\%), ASEAN Member States, 2000-2017

Source: ASEAN Secretariat, ASEANstats database.

Discussing more specific about East Java, the trade flow can be tracked from the export-import value of East Java by port. The export volume of East Java in 2017 was 13,000 million tons or equal to US\$ 19.60 billion. Tanjung Perak port of Surabaya contributed the greatest export volume that equaled to US\$ 14.92 billion. Import volume and import value of East Java were respectively 33,667 million tons or equal to US\$22.12 billion. Tanjung Perak port of Surabaya still dominated as the largest import that equaled US\$ 15.62 billion.

Table 1: Value of Export Originated from East Java, (in US\$) 2014-2017

\begin{tabular}{llllll}
\hline \multirow{2}{*}{$\begin{array}{l}\text { HS } \\
\text { Code }\end{array}$} & \multirow{2}{*}{ HS description } & \multicolumn{4}{l}{ Export Value on Selected Agriculture Product } \\
\cline { 3 - 6 } & & $\mathbf{2 0 1 4}$ & $\mathbf{2 0 1 5}$ & $\mathbf{2 0 1 6}$ & $\mathbf{2 0 1 7}$ \\
\hline 15 & Fats and Oil & $1,665,703,508$ & $1,205,976,291$ & $1,279,904,089$ & $1,389,848,720$ \\
\hline 44 & Wood & $1,010,464,656$ & $1,016,377,624$ & $1,059,062,747$ & $1,059,938,173$ \\
\hline 48 & Paper products & $921,699,233$ & $875,520,768$ & $828,643,744$ & $808,981,901$ \\
\hline 03 & Fish and Prawn & $825,290,398$ & $798,611,001$ & $841,333,626$ & $882,993,382$ \\
\hline 24 & Tobacco & $505,623,029$ & $497,711,945$ & $493,685,767$ & $542,069,172$ \\
\hline 16 & Meat and Fish Preparation & $566,569,804$ & $490,547,323$ & $476,567,915$ & $487,702,681$ \\
\hline 9 & Coffee, Tea and Spices & $332,712,102$ & $343,908,152$ & $368,387,451$ & $341,114,121$ \\
\hline 18 & Cocoa & $127,575,665$ & $236,844,514$ & $193,204,735$ & $296,242,633$ \\
\hline 20 & Fruits and Nuts & $98,497,694$ & $160,214,663$ & $115,717,898$ & $140,083,154$ \\
\hline $10-19$ & Cereal preparation & $150,332,010$ & $137,408,155$ & $120,501,063$ & $172,466,195$ \\
\hline Total Exports & $18,162,222,639$ & $16,573,581,693$ & $18,461,727,876$ & $18,410,855,057$ \\
\hline
\end{tabular}

Source: BPS Indonesia, 2018

\section{Specialization and diversification}

There are nine commodities groups (2-digit HS) in which East Javagains advantage-specialization in four consecutive years, from 2014 to 2017 (See table 4.2). Some commodities exhibit a high level of comparative advantage with RCA more than 10. For instance, Fats and Oil in 2014 showed strong RCA with 17.92, followed by Meat and Fish Preparation (11.82) and Tobacco (11.57). The last product was the specialization of East Java, as the province is the basis of major cigaret Company in Indonesia (Gudang Garam and Sampoerna by Phillip Morris). 
Table 2: Number of commodities according to RCA Result in East Java 2014-2017

\begin{tabular}{llllll}
\hline \multirow{2}{*}{ HS Code } & \multirow{2}{*}{ HS description } & \multicolumn{4}{c}{ Revealed Comparative Advantage } \\
\cline { 3 - 6 } & & $\mathbf{2 0 1 4}$ & $\mathbf{2 0 1 5}$ & $\mathbf{2 0 1 6}$ & $\mathbf{2 0 1 7}$ \\
\hline 15 & Fats and Oil & 17.92 & 13.89 & 12.62 & 13.32 \\
\hline 44 & Wood & 7.59 & 8.09 & 7.18 & 7.47 \\
\hline 48 & Paper products & 5.50 & 5.54 & 4.65 & 4.78 \\
\hline 03 & Fish and Prawn & 7.65 & 7.84 & 6.58 & 7.07 \\
\hline 24 & Tobacco & 11.57 & 12.38 & 10.42 & 11.34 \\
\hline 16 & Meat and Fish Preparation & 11.82 & 10.97 & 9.23 & 9.56 \\
\hline 9 & Coffee, Tea, and Spices & 6.94 & 7.05 & 6.52 & 6.26 \\
\hline 18 & Cocoa & 2.67 & 4.93 & 3.54 & 5.93 \\
\hline 20 & Fruits and Nuts & 1.66 & 2.72 & 1.68 & 2.15 \\
\hline $10-19$ & Cereal preparation & 0.83 & 0.79 & 0.63 & 0.94 \\
\hline
\end{tabular}

Source: Author Calculation, BPS and ITC Data 2014-2017

East Java agro-exports have strong comparative advantage-specialization for success in exports. It is noticeable that almost all agricultural commodities enjoy strong comparative advantage, from 2014 to 2017, including fats and oil, wood, paper products, fish and prawn, tobacco, meat and fish preparation, coffee, tea and spices, The rest product, Cocoa enjoyed medium comparative advantage, while Fruits and Nuts exhibits weak comparative advantage in 2014 and 2016. Cereal and cereal preparation are the commodities which have RCA below 1 from 2014 to 2017.

Table 3: Level of competitiveness according to RCA Result in East Java 2014-2017

\begin{tabular}{|c|c|c|c|c|c|}
\hline \multirow{2}{*}{$\begin{array}{l}\text { HS } \\
\text { Code }\end{array}$} & \multirow{2}{*}{ HS description } & \multicolumn{4}{|c|}{ Strong/ Medium/ Weak/ Uncompetitive } \\
\hline & & 2014 & 2015 & 2016 & 2017 \\
\hline 15 & Fats and Oil & Strong & Strong & Strong & Strong \\
\hline 44 & Wood & Strong & Strong & Strong & Strong \\
\hline 48 & Paper products & Strong & Strong & Strong & Strong \\
\hline 03 & Fish and Prawn & Strong & Strong & Strong & Strong \\
\hline 24 & Tobacco & Strong & Strong & Strong & Strong \\
\hline 16 & $\begin{array}{l}\text { Meat and Fish } \\
\text { Preparation }\end{array}$ & Strong & Strong & Strong & Strong \\
\hline 9 & Coffee, Tea, and Spices & Strong & Strong & Strong & Strong \\
\hline 18 & Cocoa & Medium & Strong & Strong & Strong \\
\hline 20 & Fruits and Nuts & Weak & Medium & Weak & Medium \\
\hline $10-19$ & Cereal preparation & Uncompetitive & Uncompetitive & Uncompetitive & Uncompetitive \\
\hline
\end{tabular}

Source: Author Calculation, BPS and ITC Data 2014-2017

\section{CONCLUSION}

East Java has experienced an important growth in agro-exports under AEC disruptive era. Myanmar, PDR Lao, Indonesia, Thailand, and Vietnam are the leaders in agricultural exports and have a high proportion of agriculture commodities to total export values.

The number of goods in which competition is weak or uncompetitive is relatively small. Since 2014, Product of Fats and oil, wood, paper products, fish and prawn, tobacco, meat and fish preparation, coffee, tea, and spices enjoy a strong comparative advantage, in which the RCA score is more than 3 . The rest product, cocoa, is starting to be stronger after 2014. Fruit and Nut are the commodities which always fluctuate between the weak and medium level of competitiveness. Cereal and cereal preparation is the only product that tended to be not competitive. In addition, agriculture production in East Java will have greater opportunities for trade expansion.

Gaining from trade appears to be far larger than losing because of international trade and opportunities for trade expansion are large, giving incentives for countries to seek how to penetrate new markets rather than to enclose themselves in anti-trade policies. Moreover, the development of a disruptive era proposes all stakeholders to perform well, ignoring business as usual efforts. 


\section{LIMITATIONS AND SUGGESTIONS}

Future Study is based on 2-digit level Harmonized System (HS) export-import data from Indonesia CentralStatisticAgencyand Internasional Trade Center (Intracen), therefore the study can not elaborate on the tradecommodity dynamics in more detail. Further study using 4-digit HS data should be conducted in order to capture more specific analysis on-competitiveness dynamics in the Indonesian sub-national level. To obtain more predictive potential and more dynamic results, Domestic Resource Cost (DRC) methods can also be used for analysis.

\section{IMPLICATIONS OF THE STUDY}

This study can be substantial for East Java economic and trade agencies to develop evidence-based policymaking in the agricultural sector. The result of the study can also be a benchmark for other provinces in Indonesia as well as another region in developing countries in which mainly depend on the agriculture sector and raw material for their international trade. Specializing the competitive agriculture commodities and developing the agricultural derivative products, as well as their supply chain, will be essential to gain from trade because the majority of export growth, is competitive under the Asean Economic Community disruptive era.

\section{ACKNOWLEDGMENT}

The authors acknowledge the support of the State University of Malang Research Grant Commission (UMRGC), especially Dean of economics and Business FacultyfortheResearch Grant Fellowship 2019.

\section{REFERENCES}

1. Acemoglu, D. (2009). Introduction to Modern Economic Growth. Princeton University Press. New Jersey.

2. Aghion, P. dan P. Howitt. (2009). The Economics of Growth. The MIT Press. Cambridge, Massachusetts, London, England.

3. ASEAN Key Figures. (2018). Jakarta: ASEAN Secretariat, December 2018

4. Badan Pusat Statistik-BPS (2019). East Java in Figure 2018. Published by Central Statistic Agency Indonesia.

5. Balassa, B., 1965. Trade liberalization and 'revealed' comparative advantage. Manchester School, 33(2): 99123. View at Google Scholar. https://doi.org/10.1111/j.1467-9957.1965.tb00050.x

6. Balassa, B., 1989. Comparative advantage, trade policy and economic development. 1st Edn., London: Harvester/ Wheat Sheaf.

7. Barro, R.J. dan Sala-i-Martin, X. (2004). Economic Growth $2^{\text {nd }}$ edition. The MIT Press. Cambridge, Massachusetts, London, England.

8. Dornbusch,Rudiger, Stanley Fischer, and Richard Startz (1998). Macroeconomics $7^{\text {th }}$ Edition. Irwin/McGrawHill.

9. Emiko, F. (2010). Revisiting Linkages Between Openness, Education and Economic Growth: System GMM Aproach. Journal of Economic Integration 25(1): 193-222. https://doi.org/10.11130/jei.2010.25.1.194

10. Enu et. all., (2013). Impact of Macroeconomic Factors on Foreign Direct Investment in Ghana: A Cointegration Analysis. European Scientific Journal October 2013 edition vol.9, No.28 ISSN: 1857 - 7881 (Print) e - ISSN 1857- 7431 .

11. Escribano et. all., (2009). Assessing the Impact of Infrastructure Quality on Firm Productivity in Africa: CrossCountry Comparisons Based on Investment Climate Surveys from 1999 to 2005. Working Paper 09-86, Economic Series (49): November 2009. https://doi.org/10.1596/1813-9450-5191

12. Erdós, T. (1973). Investment and Economic Growth. Acta Oeconomica 11(4): 281-303

13. Green, D. J. (2008). The Role of ASEAN Economic Community as a Commitment to Policy Certainty. ASEAN Economic Bulletin 25(2): 209-227. https://doi.org/10.1355/AE25-2F

14. Gupta, Satya Dev (2015). Comparative Advantage and Competitive Advantage: An Economics Perspective and a Synthesis. Athens Journal of Business and Economics. Vol. 1, No. 1. https://doi.org/10.30958/ajbe.1-1-1

15. Hseng Noan, Nang (2015) The Impact of ASEAN Transition to ASEAN Economic Community on Myanmar Economy (January 1, 2015). RSU International Journal of College of Government (RSUIJCG), Vol. 2, No. 1

16. Kementerian Luar Negeri Republik Indonesia. (2015). Masyarakat Ekonomi ASEAN (MEA). https://www.kemlu.go.id/id/kebijakan/asean/Pages/Masyarakat-Ekonomi-ASEAN-(MEA).aspx

17. Khee Giap Tan, Mulya Amri, Nurina Merdikawati, (2018). A New Index to Measure Ease of Doing Business at The Sub-National Level: Empirical Findings From Indonesia. Cross Cultural \& Strategic Management. https://doi.org/10.1108/CCSM-01-2017-0009

18. Kurniati, Yati et.al. (2007). Faktor-faktor yang Menentukan Investasi Asing Langsung. Working paper Bank Indonesia. WP/06/2007

19. Lee, J. (1995). Comparative Advantage in Manufacturing as a Determinant of Industrialization: The Korean Case, World Development, Vol. 23, No. 7, pp. 1195-1214. ISSN 0305-750X. https://doi.org/10.1016/0305750X(95)00039-F

20. Mankiw, N.G., D. Romer and D.N. Weil. (1992). A Contribution to the Empirics of Economic Growth. Quarterly Journal of Economics 107: 407-437. https://doi.org/10.2307/2118477 
21. Majid, M. (2016). Forging the ASEAN Economic Community, 2015 to 2016 - and Beyond. Southeast Asian Affairs 18(2): 43-54. https://doi.org/10.1355/9789814762878-006

22. Sahoo, Pravakar (2006). Foreign Direct Investment in South Asia: Policy, Trends, Impact and Determinants. ADB Institute Discussion Paper No. 56

23. The World Economic Forum (2018). The Global Competitiveness Index 2018. Published by The World Economic Forum.

24. Tongzon, J.L. (2003). US - Singapore Free Trade Agreement: Implications for ASEAN. ASEAN Economic Bulletin 20(2): 174-178. https://doi.org/10.1355/AE20-2F

25. Widodo, T. (2009). Comparative Advantage: Theory, Empirical Measures and Case Studies, Review of Economic and Business Studies, Vol 4, pp. 57-82. ISSN 2068-7249.

26. Yasmin, B., Hussain, A., and Chaudhary, M. A. (2003). Analysis Factors Affecting Foreign Direct Investmen In Developing Countries. Pakistan Economic and Social Review, 41(1\&2): 59-75.

27. Yue, Ch. and Hua, P.. (2002). Does Comparative Advantage Explains Export Patterns in China?, China Economic Review, Vol. 13, No. 2, pp. 276 - 96. ISSN 1043-951X. https://doi.org/10.1016/S1043$\underline{951 X(02) 00073-1}$ 